\title{
Development and stability assessment of liquid paediatric formulations containing sildenafil citrate
}

\author{
Fátima Roque ${ }^{1,2}$, Ana Cristina Rama ${ }^{2,3}$, João José Sousa², Maria Eugénia Pina² \\ ${ }^{1}$ Research Unit for Inland Development, Polytechnic Institute of Guarda, ${ }^{2}$ Center of Pharmaceutical Studies, Faculty of \\ Pharmacy, University of Coimbra, ${ }^{3}$ University of Coimbra Hospital
}

\begin{abstract}
The purpose of this study is to develop and improve oral liquids formulations of sildenafil citrate for paediatric use. Four different formulations were developed, which are as follows: two aqueous solutions of sildenafil citrate $(2.5 \mathrm{mg} / \mathrm{mL})$, with or without preservatives, and two other solutions of sildenafil in simple syrup $(1.25 \mathrm{mg} / \mathrm{mL})$, with or without preservatives. All of the formulations were physically, chemically and microbiologically stable for three months. The results of the stability studies allowed for the optimisation of formulations without preservatives due to their simplicity and their similar stable conditions when compared to the formulations containing antimicrobials. The shelf life of both formulations was three months; however, upon opening, aqueous solutions should be used within 10 days and kept refrigerated, and syrup solutions should be used within 14 days in a hospital setting.
\end{abstract}

Uniterms: Chemical stability. Microbiological stability. Sildenafil citrate. Paediatric formulations.

O objetivo deste trabalho é desenvolver e otimizar formulações líquidas orais de citrato de sildenafil adequadas ao uso pediátrico. Foram desenvolvidas quatro formulações diferentes: duas soluções aquosas de citrato de sildenafila $(2,5 \mathrm{mg} / \mathrm{mL})$ com ou sem conservantes e duas soluções de citrato de sildenafil em xarope simples $(1,25 \mathrm{mg} / \mathrm{mL})$ com ou sem conservantes. Todas as formulações desenvolvidas apresentaram estabilidade quer físico-química quer microbiológica durante 3 meses. Os resultados dos estudos de estabilidade permitiram otimizar as formulações isentas de conservantes, uma vez que estas eram mais simples e apresentavam do mesmo modo uma boa estabilidade, comparando com as formulações que continham conservantes. O período de utilização de ambas as formulações é de três meses, no entanto, após abertura do frasco, a solução aquosa deve ser utilizada durante 10 dias, acondicionada no refrigerador e o xarope deve ser utilizado durante 14 dias, mesmo em ambiente hospitalar.

Unitermos: Estabilidade química. Estabilidade microbiológica. Citrato de sildenafil. Formulações pediátricas.

\section{INTRODUCTION}

The lack of commercially available oral liquid dosage forms adequate for paediatric use remains a problem in many practice settings. Indeed, many medicines used to treat children are either unlicensed or are prescribed off-label (Tafuri et al., 2009; Kairuz et al., 2007). A literature review (Pandolfini, 2005) revealed that off-label/unlicensed prescription rates ranged from

Correspondence: M. E. Pina. Center of Pharmaceutical Studies (CEF), Faculty of Pharmacy, University of Coimbra. Azinhaga de Santa Comba, 3000-548 Coimbra - Portugal. E-mail: epina@ci.uc.pt
$11 \%$ to $80 \%$, and higher rates were found in younger versus older patients and in hospital versus community settings. In paediatric hospital wards, the use of off-label/ unlicensed prescriptions ranged from $16 \%$ to $62 \%$, and in the community setting, use rates ranged from $11 \%$ to $37 \%$ (Pandolfini, 2005). Up to $90 \%$ of medicinal products used in neonates are off-label or unlicensed (EMEA, 2009).

Problems resulting from the absence of appropriate medicinal products for the paediatric population include inadequate dosage information, which leads to an increased risk of adverse reactions including death; ineffective treatment through under-dosage; inability to access therapeutic advances for paediatric populations; 
lack of suitable formulations; lack of appropriate routes of administration; as well as the use of magistral or official formulations, which may be of poor quality for the treatment of paediatric populations (EMEA, 2006; EU, 2006). A study conducted in the United Kingdom showed that $54 \%$ of 112 paediatric extemporaneous formulations had inadequate data to guarantee their quality during the period of use (Brion, 2003). Many studies have been published with the purpose of assessing the extent to which formulations not studied in children are used. These studies have increased awareness of the need to develop new formulations suitable for paediatric use, which take into account the evaluation of their quality and stability using adequate stability studies (Jong et al., 2002; Schirm, 2003; Grieve et al., 2005; Ceci et al., 2006; Ghulam et al., 2007).

An example of an unlicensed and off-label use of a medication in children and neonates is the extemporaneous preparation of sildenafil citrate from tablets, as a liquid preparation of sildenafil citrate is not commercially available. Sildenafil citrate has been used to treat pulmonary arterial hypertension (PAH) in children and neonates. A number of review papers and case reports on the use of oral sildenafil citrate as a treatment for PAH of different aetiologies in children have been published (Fernández-González et al., 2004; GarcíaMartinez et al., 2003; Humpl et al., 2005; Keller et al., 2004; Kothari, 2002; Ladha et al., 2005; Leibovitch, 2007; Namachivayam et al., 2006; Barnett, 2006). These published documents demonstrate the efficacy and safety of sildenafil citrate in the paediatric population, including newborns. Because the only commercially available dosage form of sildenafil citrate is tablets, it is important to develop a liquid formulation of sildenafil citrate of adequate quality and stability to treat the paediatric population. Nahata (2006) developed two extemporaneous sildenafil citrate oral suspensions from commercial tablets using methylcellulose and simple syrup as the vehicle or ready-to-use preparations of Ora-Plus and Ora-Sweet. However, in these formulations, all of the excipients included on the tablets are concomitantly administered to children.

Manipulating adult medicine products into paediatric forms should be considered a secondary option to be performed only when the pure active ingredient is not available (EMEA, 2006). Given this, the aim of this study was to develop an oral liquid formulation of sildenafil citrate, as it is an important drug used in the paediatric population, including neonates, for the treatment of PAH. The formulations were kept as simple as possible and were prepared from pure active ingredients and not from commercial tablets, to avoid the potentially undesirable adverse effects of excipients (EMEA, 2006; American Academy of Pediatrics, 1997).

\section{MATERIAL AND METHODS}

\section{Chemical and reagents}

Sildenafil citrate, pure active ingredient (99.2\%), Lot SDC/0610003, was obtained from Matrix Laboratories Limited, Secunderab - India. Methylparaben (99\%), lot J7646A, and propylparaben (99\%), lot D9626A, were obtained from Alfa Aesar GmbH, Kalsruhe, Germany. Propylenoglycol of analytical grade, lot 437727/1, was obtained from Alpha Chemika, Maharashatra India, and sucrose, G001, was obtained from SIDUL, Santa Iria Azoia, Portugal. Purified water was obtained from Millipore system Millipore Corporation Progrard ${ }^{\mathrm{TM}}{ }^{\circledR}$, USA.

A solution of methylparaben and propylparaben $(10 \%, 7: 3, \mathrm{w} / \mathrm{v})$ in propylenoglycol was also used after filtration.

\section{Preparation of solutions}

Four different solutions were prepared:

1. An aqueous solution of sildenafil citrate $2.5 \mathrm{mg} / \mathrm{mL}$ containing preservatives

2. An aqueous solution of preservative-free sildenafil citrate $2.5 \mathrm{mg} / \mathrm{mL}$

3. A solution of sildenafil citrate $1.25 \mathrm{mg} / \mathrm{mL}$ in simple syrup containing preservatives

4. A preservative-free solution of sildenafil citrate $1.25 \mathrm{mg} / \mathrm{mL}$ in simple syrup

Three preparations of each formulation were prepared. All preparations were stored in well-closed $60 \mathrm{~mL}$ amber, Type III glass bottles, lot $\mathrm{n}^{\circ} 266077$ obtained from Saint-Gobain La Grange, Segovia, Spain.

\section{Method of preparation used for preservative-free aqueous solution sildenafil citrate $2.5 \mathrm{mg} / \mathrm{mL}$}

1. The required quantity of each ingredient for a $250 \mathrm{~mL}$ solution to be prepared was calculated.

2. Each ingredient was accurately weighed and/or measured.

3. Six hundred twenty-five milligrams of sildenafil citrate was dissolved with $250 \mathrm{~mL}$ of water in a graduated cylinder for 20 minutes under magnetic agitation using a $30^{\circ} \mathrm{C}$ water bath, Emílio de 
Azevedo Campos, Portugal. The final solution was filtered.

\section{Method of preparation for aqueous solution sildenafil citrate $2.5 \mathrm{mg} / \mathrm{mL}$ containing preservatives}

1. The required quantity of each ingredient for a $250 \mathrm{~mL}$ solution to be prepared was calculated.

2. Each ingredient was accurately weighed and/or measured.

3. $625 \mathrm{mg}$ of sildenafil citrate was dissolved with $200 \mathrm{~mL}$ of water in a $250-\mathrm{mL}$ volumetric flask.

4. A solution of $2.4 \mathrm{~mL}$ of methylparaben and propylparaben was added to step 3 .

5. Sufficient water was added to obtain a sufficient volume.

6. The dissolution was carried out with magnetic agitation using a $30{ }^{\circ} \mathrm{C}$ water bath, and the solution obtained was filtered.

\section{Method of preparation for a preservative-free solution of sildenafil citrate in syrup $1.25 \mathrm{mg} / \mathrm{mL}$}

1. The required quantity of each ingredient for a $250 \mathrm{~mL}$ solution to be prepared was calculated.

2. Each ingredient was accurately weighed and/or measured.

3. Then, $312.5 \mathrm{mg}$ of sildenafil citrate was dissolved in $110 \mathrm{~mL}$ of water under magnetic agitation for 20 minutes using a $30^{\circ} \mathrm{C}$ water bath.

4. $220 \mathrm{~g}$ of sucrose was added and dissolved under agitation until a limpid solution was obtained and was followed by filtration.

\section{Method of preparation for a solution of sildenafil citrate in syrup $1.25 \mathrm{mg} / \mathrm{mL}$ containing preservatives}

1. The required quantity of each ingredient for a $250 \mathrm{~mL}$ solution to be prepared was calculated.

2. Each ingredient was accurately weighed and/or measured.

3. Then, $312.5 \mathrm{mg}$ of sildenafil citrate was dissolved in $110 \mathrm{~mL}$ of water under magnetic agitation for 20 minutes using a $30^{\circ} \mathrm{C}$ water bath.

4. A solution of $2.4 \mathrm{~mL}$ of methylparaben and propylparaben was added under agitation to complete dissolution.

5. $220 \mathrm{~g}$ of sucrose was added while maintaining the agitation until a limpid solution was obtained, followed by filtration.

\section{Analytical method}

\section{Observation of Preparations}

Samples were checked for organoleptic characteristics.

\section{Measurement of $\mathrm{pH}$}

The $\mathrm{pH}$ was immediately measured in all preparations and throughout the stability study (Meter pH 526, Multicar ${ }^{\circledR}$, WTW, Germany).

\section{Sildenafil Citrate Content}

Sildenafil citrate content was determined after preparation and throughout the stability study using ultraviolet-visible (UV-VIS) spectrophotometric method at $292 \mathrm{~nm}$ (Shimadzu UV-Visible 1603, Shimadzu, Japan). The analytical methodology was validated for selectivity, linearity, precision, and accuracy. No interference of excipients was observed. The linearity of the standard curve was determined by linear regression analysis of sildenafil citrate concentrations versus absorbance values (Figure 1). The correlation factor was 0.999 , with intraday and interday coefficients of variation of 0.1 and 1.8 , respectively. The percentage of recovery changed from 100.6 to 101.4 and 101.1 to 101.8 in the presence of the parabens or sucrose, respectively.

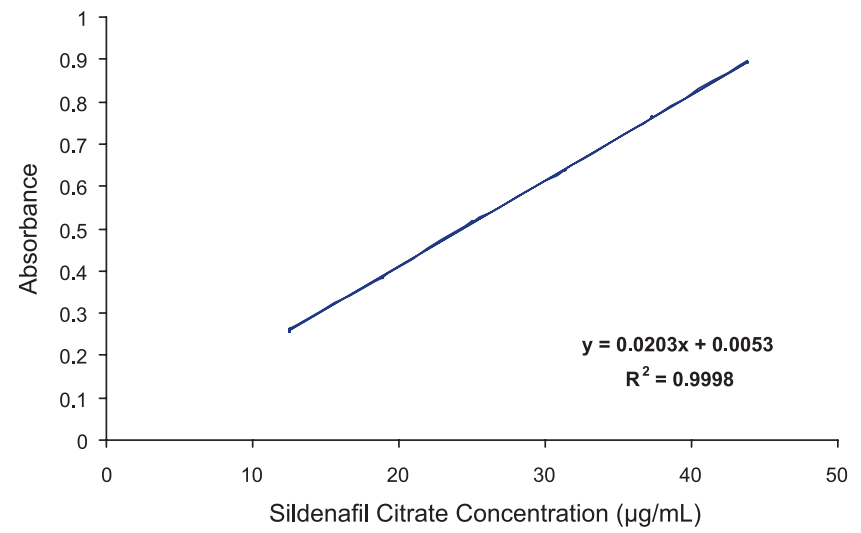

FIGURE 1 - Standard curve of determination of Sildenafil Citrate Content using the spectrophotometric method.

\section{Stability studies}

Protocols for stability studies have been performed according to the Committee for Proprietary Medicinal Product's Guidelines on Stability Testing: Stability Testing of Existing Active Substances and Related Finished Products 10 (CPMP, 2003a).

\section{Chemical stability studies}

Twelve sildenafil citrate solutions were prepared. 
Six solutions were aqueous; of these, three contained preservatives, and the other three were preservative free. Another six solutions were prepared in simple syrup. Of these, three were prepared with preservatives, and the other three were preservative free. Stability was evaluated for three months, during which time the preparations were stored in a chamber (Heraeus, Alemanha) under controlled conditions at $5{ }^{\circ} \mathrm{C} \pm 3{ }^{\circ} \mathrm{C}$ and $25^{\circ} \mathrm{C} \pm 2{ }^{\circ} \mathrm{C} / 60 \% \mathrm{RH} \pm 5 \%$ RH. Samples were collected at days 0, 7, 14, 28, 42, 56, 70, and 91. Appearance, $\mathrm{pH}$, and sildenafil citrate content were evaluated.

\section{Microbiological stability studies}

The microbiological quality of sildenafil citrate solutions stored during stability studies was assessed according to European Pharmacopoeia (EP, 2005) Monograph 5.1.4.-Microbiological Quality of Pharmaceutical Preparations. Microbial examination was performed by counting total viable aerobic microorganisms using the plate-count method based on the $E P$ from 2.6.12. Microbial Examination of Non-Sterile Products: Total Viable Aerobic Count.

\section{In-use stability}

Preservative-free solutions were submitted to in-use stability tests, in both hospital and ambulatory conditions, for 10 (aqueous solutions) and 14 days (syrup solutions), according to the Committee for Proprietary Medicinal Product's Note for Guidance on In-use Stability Testing of Human Medicinal Products (CPMP, 2001).

\section{RESULTS}

\section{Chemical stability}

Aqueous sildenafil citrate solutions, with and without preservatives, were limpid, colourless, and odourless solutions with a slight bitter taste. Sildenafil citrate in simple syrup, with and without preservatives was limpid, yellowish, and had a sweet taste. Both solutions remained unchanged in appearance at selected temperatures throughout the stability study. The $\mathrm{pH}$ values remained fairly constant without significant changes in the preparations (Figures 2,3). At the end of stability studies under $5{ }^{\circ} \mathrm{C} \pm 3{ }^{\circ} \mathrm{C}$, the $\mathrm{pH}$ of preservative-free aqueous solutions was the same as the initial determination ( $\mathrm{pH}=4.02$ ) with no significant changes during study determinations (Figure 2). At day 91, the aqueous solutions with preservative had the same $\mathrm{pH}$, independent of storage conditions; $\mathrm{pH}$ values ranged from $3.84 \pm 0.15$ or $3.98 \pm 0.04$ on day 28 and $4.11 \pm 0.09$ on day 91 (Figure 2 ).
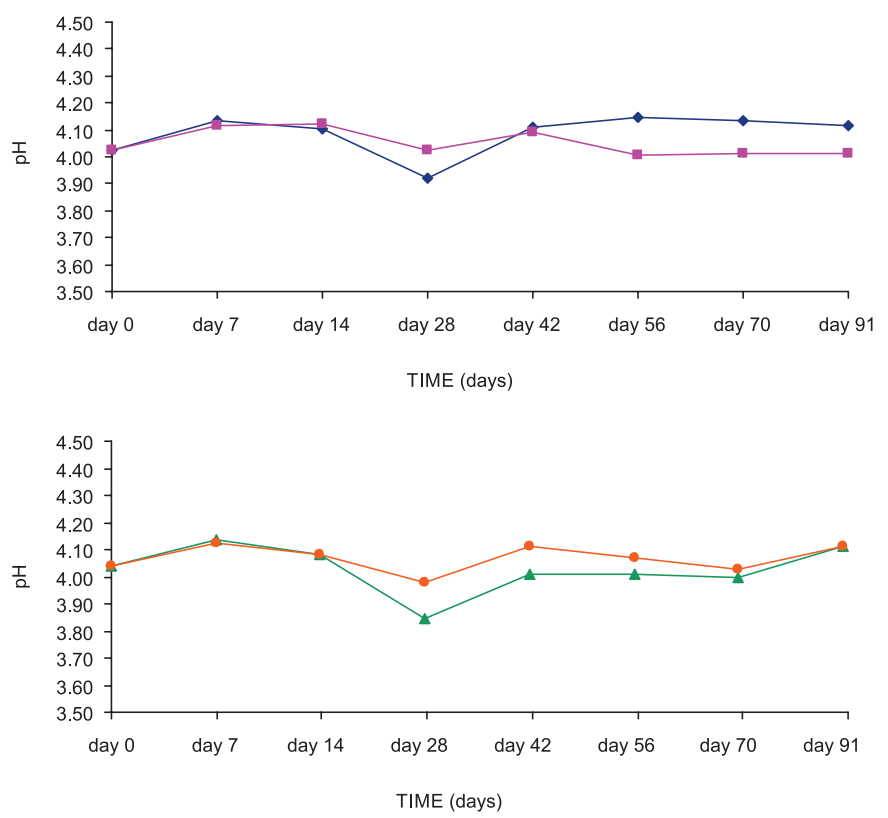

FIGURE 2 - The $\mathrm{pH}$ variation of sildenafil citrate aqueous solutions (mean \pm standard deviation; $n=3$ ). $\diamond$ preservative-free solution stored at $5{ }^{\circ} \mathrm{C} \pm 3{ }^{\circ} \mathrm{C}$ and $\square$ stored at $25^{\circ} \mathrm{C} \pm 2{ }^{\circ} \mathrm{C} / 60 \%$ $\mathrm{RH} \pm 5 \% \mathrm{RH} \Delta$ solution containing preservative stored at $5{ }^{\circ} \mathrm{C}$ $\pm 3{ }^{\circ} \mathrm{C}$ and $\bigcirc$ stored at $25^{\circ} \mathrm{C} \pm 2{ }^{\circ} \mathrm{C} / 60 \% \mathrm{RH} \pm 5 \% \mathrm{RH}$.

The $\mathrm{pH}$ values of syrup solutions were slightly higher than aqueous solutions. In preservative-free syrup solutions, $\mathrm{pH}$ values changed from $4.27 \pm 0.06$ at the beginning of the stability studies to $4.30 \pm 0.02$ or $4.26 \pm 0.13$ at the end of the studies, respectively, at $5{ }^{\circ} \mathrm{C}$ or $25^{\circ} \mathrm{C}$ (Figure 3). Initially, the $\mathrm{pH}$ in the syrup solutions containing preservatives was $4.30 \pm 0.1$, and during stability determinations, the values ranged from $4.22 \pm 0.04$ to $4.32 \pm 0.02$ at $5{ }^{\circ} \mathrm{C}$ or between $4.19 \pm 0.1$ and $4.34 \pm 0.1$ at $25^{\circ} \mathrm{C}$ (Figure 3 ).

\section{Sildenafil Citrate Content}

Analytical results show that sildenafil citrate content in all preparations remained above $95 \%(\mathrm{w} / \mathrm{v})$ throughout 91 days in both conditions (Figures 4, 5). Initially, the percentage of sildenafil citrate content in preservativefree aqueous solutions was $100.75 \pm 0.96$. At the end of 3 months, the percentages of sildenafil citrate content were $100.04 \pm 0.52$ at $25^{\circ} \mathrm{C}$ and $101.69 \pm 1.02$ at $5^{\circ} \mathrm{C}$ (Figure 4). At day 91, the percentages of sildenafil citrate content in solutions with preservative were $101.86 \pm 1.30$ at $25^{\circ} \mathrm{C}$ and $102.97 \pm 0.34$ at $5{ }^{\circ} \mathrm{C}$.

The percentages of sildenafil citrate content in preservative-free syrup solutions on day 91 were $99.19 \pm 2.75$ and $98.97 \pm 0.99$ at $25^{\circ} \mathrm{C}$ and $5{ }^{\circ} \mathrm{C}$, respectively. In solutions containing preservatives, the 
percentages of sildenafil citrate content were $98.31 \pm 2.65$ and $98.97 \pm 0.99$ at $25^{\circ} \mathrm{C}$ and $5^{\circ} \mathrm{C}$, respectively (Figure 5).
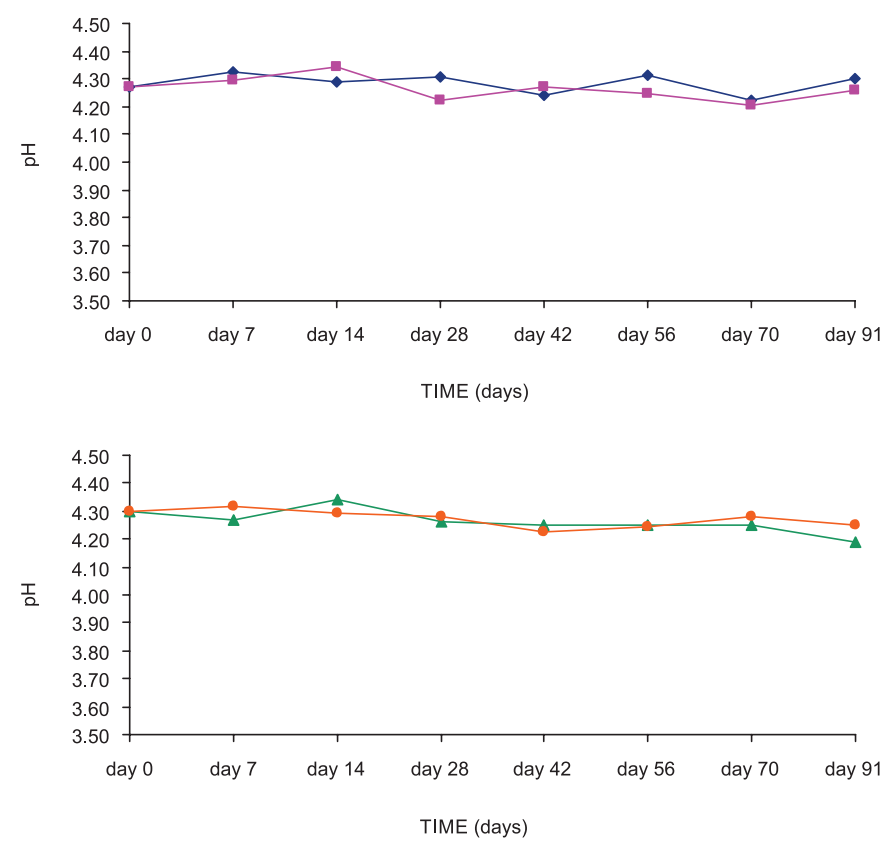

FIGURE 3 - The $\mathrm{pH}$ variation of sildenafil citrate syrup solutions (mean \pm standard deviation; $n=3$ ). $\diamond$ preservative-free solution stored at $5{ }^{\circ} \mathrm{C} \pm 3{ }^{\circ} \mathrm{C}$ and $\square$ stored at $25^{\circ} \mathrm{C} \pm 2{ }^{\circ} \mathrm{C} / 60 \% \mathrm{RH} \pm 5 \%$ RH $\triangle$ solution containing preservative stored at $5{ }^{\circ} \mathrm{C} \pm 3{ }^{\circ} \mathrm{C}$ and stored at $25^{\circ} \mathrm{C} \pm 2{ }^{\circ} \mathrm{C} / 60 \% \mathrm{RH} \pm 5 \% \mathrm{RH}$.
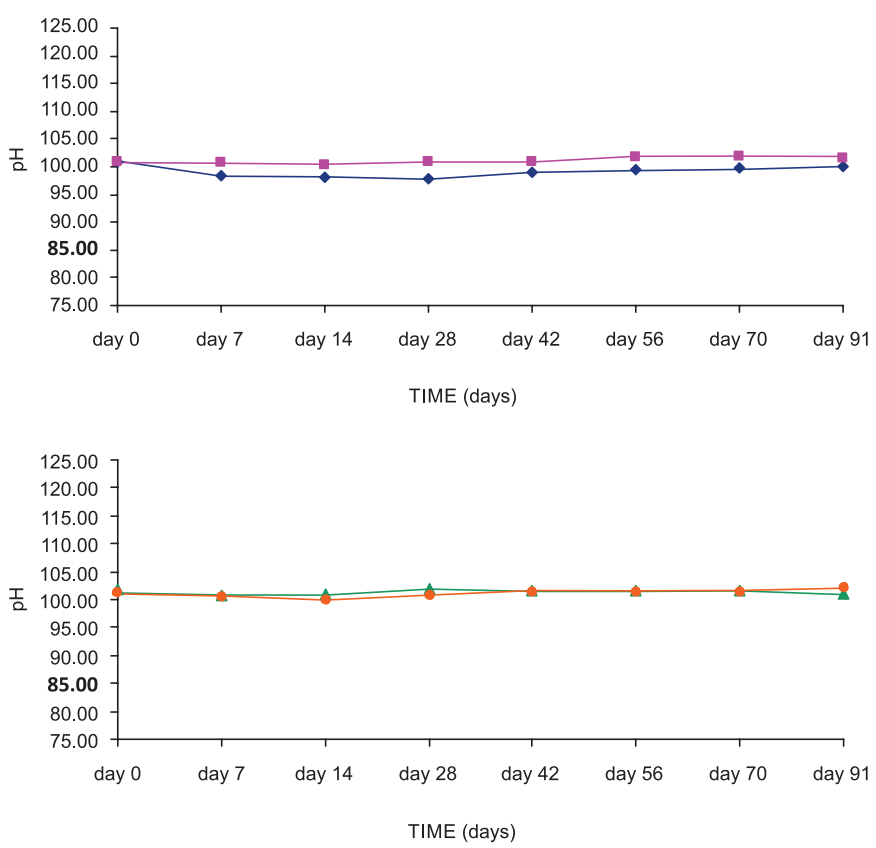

FIGURE 4 - Sildenafil citrate content (\%) variation on aqueous solutions (mean \pm standard deviation; $n=3$ ). $\diamond$ preservative-free solution stored at $5{ }^{\circ} \mathrm{C} \pm 3{ }^{\circ} \mathrm{C}$ and $\square$ stored at $25^{\circ} \mathrm{C} \pm 2{ }^{\circ} \mathrm{C} / 60 \%$ $\mathrm{RH} \pm 5 \% \mathrm{RH} \triangle$ solution containing preservative stored at $5^{\circ} \mathrm{C}$ $\pm 3{ }^{\circ} \mathrm{C}$ and $\bigcirc$ stored at $25^{\circ} \mathrm{C} \pm 2{ }^{\circ} \mathrm{C} / 60 \% \mathrm{RH} \pm 5 \% \mathrm{RH}$.
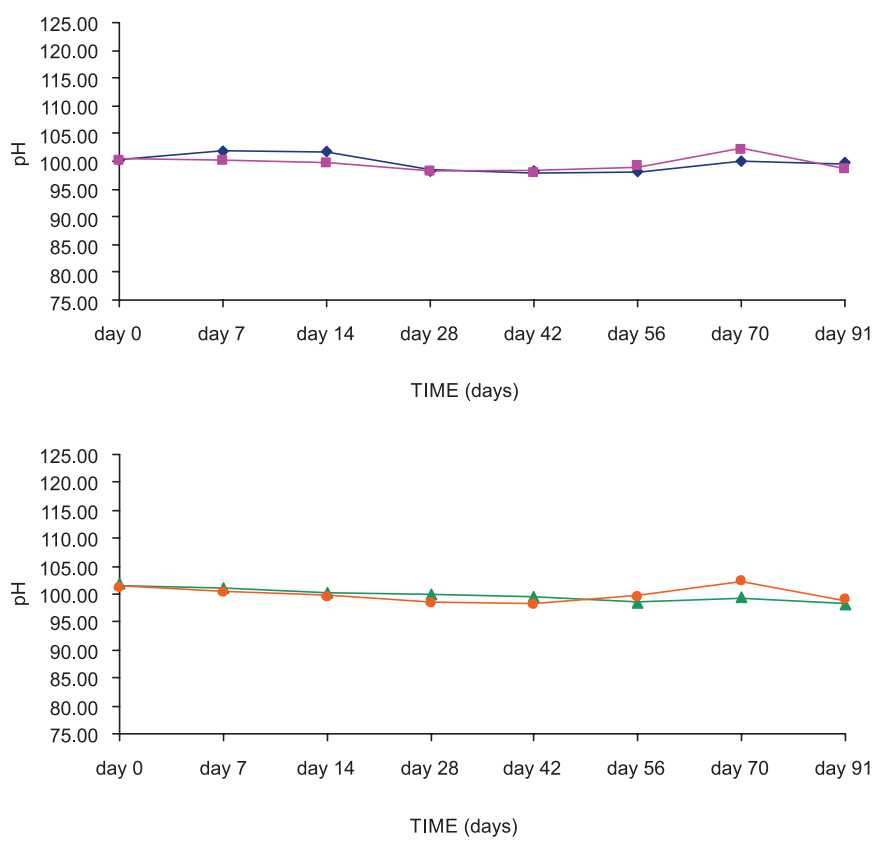

FIGURE 5 - Sildenafil citrate content (\%) variation on syrup solutions (mean \pm standard deviation; $n=3$ ). $\diamond$ preservative-free solution stored at $5^{\circ} \mathrm{C} \pm 3{ }^{\circ} \mathrm{C}$ and $\square$ stored at $25^{\circ} \mathrm{C} \pm 2{ }^{\circ} \mathrm{C} / 60 \%$ $\mathrm{RH} \pm 5 \% \mathrm{RH} \Delta$ solution containing preservative stored at $5{ }^{\circ} \mathrm{C}$ $\pm 3{ }^{\circ} \mathrm{C}$ and $\bigcirc$ stored at $25^{\circ} \mathrm{C} \pm 2{ }^{\circ} \mathrm{C} / 60 \% \mathrm{RH} \pm 5 \% \mathrm{RH}$.

\section{Microbiological stability}

At the end of stability testing, all preparations were in accordance with EP's Microbiological Quality of Pharmaceutical Preparations, i.e., there was an absence of Escherichia coli, and the total viable aerobic count were below $10^{3}$ bacteria and not more than $10^{2}$ fungi per gram or per millilitre. Neither preservative-free solutions nor solutions containing preservative exhibited the development of microorganisms in storage conditions at $25^{\circ} \mathrm{C}$ and $5{ }^{\circ} \mathrm{C}$. This indicates that there is no advantage in using preservatives in these formulations.

\section{In-use stability}

Because we suggest a multi-dose immediate container, it was necessary to determine the stability of the preparations once the container is open. These studies were carried out on preservative-free solutions. Containers of aqueous and syrup solutions were opened twice a day at the hospital and at home. A 1-mL sample was removed from each preparation to simulate real conditions of use. This procedure occurred over 10 consecutive days for aqueous solutions and 14 days for syrup solutions; physicochemical and microbiological parameters were then determined. 
TABLE I - Results of physicochemical determinations after in-use stability studies

\begin{tabular}{lcccc}
\hline \multirow{2}{*}{ Tests } & \multicolumn{2}{c}{ Aqueous Solution } & \multicolumn{2}{c}{ Syrup Solution } \\
\cline { 2 - 5 } Observation & Home & Hospital & Home & Hospital \\
\hline $\begin{array}{l}\text { Sildenafil citrate } \\
\text { content (\%) }\end{array}$ & $\begin{array}{c}\text { Colourless limpid } \\
\text { solution, with a slight } \\
\text { bitter taste }\end{array}$ & $\begin{array}{c}\text { Colourless limpid } \\
\text { solution, with a slight } \\
\text { bitter taste }\end{array}$ & $\begin{array}{c}\text { Yellowish limpid } \\
\text { solution, with a sweet } \\
\text { taste }\end{array}$ & $\begin{array}{c}\text { Yellowish limpid } \\
\text { solution, with a sweet } \\
\text { taste }\end{array}$ \\
\hline pH & 100.17 & 100.83 & 100.43 & 100.50 \\
& $(2.504 \mathrm{mg} / \mathrm{mL})$ & $(2.520 \mathrm{mg} / \mathrm{mL})$ & $(1.255 \mathrm{mg} / \mathrm{mL})$ & $(1.256 \mathrm{mg} / \mathrm{mL})$ \\
\hline
\end{tabular}

\section{Physicochemical stability}

The results demonstrate that both solutions remained unchanged in appearance, $\mathrm{pH}$, and active ingredient content (Table I) in both simulation conditions.

\section{Microbiological stability}

In solutions that both contained preservative and solutions that were preservative-free, which were either stored at home or at the hospital, it was determined that microbial contamination, according to $E P$ and the results of this study, demonstrated the absence of Escherichia coli. The results of microbial contamination expressed as total aerobic viable counts showed $40 \mathrm{cfu} / \mathrm{mL}$ for aqueous solutions stored at the hospital and no development of colonies in aqueous solutions stored at home or in syrup solutions used at home or in the hospital. In syrup solutions, the high level of sucrose plays an antimicrobial role. Although some development of germs was observed, in aqueous solutions used at the hospital, the values were much lower than the test limit present in the $E P$ specifications.

\section{DISCUSSION}

Although excipients should be pharmacologically inactive, they may indeed cause adverse effects. It is important to consider that the physiology of neonates and infants differs considerably from that of adults. They may not be able to metabolise or eliminate an ingredient in a pharmaceutical product in the same manner as an adult (EMEA, 2006). It is common pharmacy practice when compounding extemporaneous oral liquid preparations from a commercially available solid oral dosage form for a paediatric patient who crushed tablets or the contents of a capsule are solubilised or suspended by the addition of water or juice. However, there are often limited data to support the stability or bioavailability of the final liquid dosage form and the potential interactions between the excipients subjected to those procedures (Glass, 2006).
During this study, sildenafil citrate solutions were kept as simple as possible and were prepared from pure active ingredients rather than from commercial tablets to avoid potential undesirable effects due to excipients.

Antioxidants and antimicrobial preservatives are ingredients that are used to increase the stability of medicines by retarding the oxidation of active ingredients and excipients or by reducing microbial proliferation. Certain chemical groups that make up the properties of these ingredients are usually aggressive towards living cells and lead to certain risks when used in humans. If these additional ingredients are not needed, then they should be avoided (CPMP, 2003b). Given this fact, we have prepared two very simple solutions: an aqueous solution and a syrup solution of sildenafil citrate without preservatives. Nonsterile liquid formulations are easily contaminated by microbial agents, and we know that nosocomial infections are significant causes of mortality in newborns and infants who require intensive care. This evidence justifies the inclusion of preservatives in test formulations. Propylparaben and methylparaben are stable compounds that have been used as antimicrobial preservatives in foods, drugs, and cosmetics for over 50 years. The association of methylparaben and propylparaben promotes a better antimicrobial action (Soni, $2001,2002)$. Both the solutions containing preservatives and the preservative-free solutions retained their potency during the three months of the stability study. Appearance and $\mathrm{pH}$ values also remained unchanged. At the end of the stability study, no microbiological contamination was found in either solutions containing preservatives or preservativefree solutions, at $5{ }^{\circ} \mathrm{C}$ or $25^{\circ} \mathrm{C}$, showing that sildenafil citrate aqueous and syrup solutions are chemically and microbiologically stable.

In-use stability tests were designed to detect the stability of preservative-free solutions in real conditions of use after first vial opening. In those samples stored at the hospital, microbial growth $(40 \mathrm{cfu} / \mathrm{mL})$ was detected in aqueous solutions; however, this value is below pharmaceutical specifications. In the syrup solutions, no 
microbiological contamination was detected in either those samples used at home or at the hospital. Although these are promising results, the authors recommended that after the first use, the preparations should be stored in a refrigerator.

\section{CONCLUSION}

The results of this study indicate that sildenafil citrate is stable in both aqueous and syrup solutions without preservatives when packed in an amber glass bottle at both $25^{\circ} \mathrm{C}$ and at $5{ }^{\circ} \mathrm{C}$ for 91 days. Based on these results, a 3 -month shelf life can be assigned for these preparations. The studied formulations are very simple, containing only water or simple syrup as a vehicle, which is very important when formulations are created for paediatric use. When the vial is first opened, its contents are exposed to atmospheric oxygen and microbial invasion. In-use stability studies indicated that preparations of aqueous solutions could be used within 10 days, and syrup solutions could be used within 14 days after first use.

\section{REFERENCES}

AMERICAN ACADEMY OF PEDIATRICS. Committee on drugs. "Inactive" ingredients in pharmaceutical products: update (subject review). Pediatrics, v.99, n.2, p.268-278, 1997.

BARNETT, C.F.; MACHADO, R.F. Sildenafil in the treatment of pulmonary hypertension. Vasc. Health Risk. Manag., v.2, n.4, p.411-422, 2006.

BRION, F.; NUNN, A.; RIEUTORD, A. Extemporaneous (magistral) preparation of oral medicines for children in European hospitals. Acta Paediatr., v.92, n.4, p.486-490, 2003.

CECI, A.; FELISI, M.; BAIARDI, P.; CATAPANO, M.; GIAQUINTO, C.; NICOLOSI, A.; STURKENBOOM, M.; NEUBERT, A.; WONG, I. Medicines for children licensed by the European Medicines Agency (EMEA): the balance after 10 years. Eur. J. Clin. Pharmacol., v.62, n.11, p.947$952,2006$.

COMMITTEE FOR PROPRIETARY MEDICINAL PRODUCTS. CPMP. Note for guidance on excipients, antioxidants and antimicrobial preservatives, in the dossier for application for marketing authorization of medicinal products (CPMP/QWP/419/03). Available at: <http:// www.emea.europa.eu/pdfs/human/qwp/041903en.pdf>. Accessed on: 16 Jul. 2008.
COMMITTEE FOR PROPRIETARY MEDICINAL PRODUCTS. CPMP Guideline on Stability Testing: Stability Testing of Existing Active Substances and Related Finished Products (CPMP/QWP/122/02). Available at: $<$ http://www.emea.europa.eu/pdfs/human/qwp/012202en. pdf $>$. Accessed on: 7 Sep. 2008.

COMMITTEE FOR PROPRIETARY MEDICINAL PRODUCTS. CPMP. Note for Guidance on In-use Stability Testing of Human Medicinal Products (CPMP/ QWP/2934/99), 01 Mar. 2001. Available at: <http:// www.emea.europa.eu/pdfs/human/qwp/293499en.pdf $>$. Accessed on: 7 Sep. 2008.

\section{EUROPEAN PARLIAMENTAND COUNCILOF EUROPEAN} UNION. Regulation (EC) No. 1901/2006 of the European Parliament and of the Council of 12 December 2006 on Medicinal Products for Paediatric Use. Official Journal of the European Union, 2006. Available at: <http://eur-lex. europa.eu/LexUriServ/LexUriServ.do?uri= CONSLEG: 2006R1901:20070126:PT:PDF>. Accessed on: 18 Mar. 2010

European Medicine Evaluation Agency (EMEA), Committee for Medicinal Products for Human Use (CHMP) and Paediatric Committee (PDCO). Guideline on the Investigation of Medicinal Products in the Term and Preterm Neonate EMEA/536810/2008, 25 jun. 2009. Available at: http:// www.ema.europa.eu/docs/en_GB/document_library/ Scientific guideline/2009/09/WC 500003750.pdf. Accessed on: 01 Apr. 2010.

European Medicine Evaluation Agency (EMEA), Committee for Medicinal Products for Human Use (CHMP). Reflection paper: formulations of choice for the paediatric population. EMEA/CHMP/PEG/194810/2005, 28 July 2006. Available at: $<$ http://www.emea.europa.eu/pdfs/human/ paediatrics/19481005en.pdf $>$.

EUROPEAN Pharmacopoeia. 5ed. Council of Europe, 2005. p.157-164, 519-520.

GONZALEZ, N.F.; FERNANDEZ, A.R.; ROJAS, J.J.; GARRIDO, S.M.P.; MENGUAL, L.M. Oral sildenafil: a promising drug for persistent neonatal pulmonary hypertension. An. Pediatr. (Barc)., v.61, n.6, p.567-568, 2004. 
GHUlAM, A.; KEEN, K.; TULEU C., WONG, I.C. Poor preservation efficacy versus quality and safety of pediatric extemporaneous liquids. Ann. Pharmacother, v.41, n.5, p.857-860, 2007.

GLASS, B.D.; HAYWOOD, A. Stability considerations in liquid dosage forms extemporaneously prepared from commercially available products. J. Pharm. Pharm. Sci., v.9, n.3, p.398-426, 2006.

GRIEVE, J.; TORDOF, J., REITH, D.; NORRIS, P. Effect of the pediatric exclusivity provision on children's access to medicines. Br. J. Clin. Pharmacol., v.59, n.6, p.730-735, 2005.

HUMPL, T.; REYES, J.T.; HOLTBY, H.; STEPHENS, D.; ADATIA, I. Beneficial effect of oral sildenafil therapy on childhood pulmonary arterial hypertension: twelve-month clinical trial of a single-drug, open-label, pilot study. Circulation, v.111, n.24, p.3274-3280, 2005.

JONG, G.W.; ELAND, I.A.; STURKENBOON, M.C.; ANKER, J.N. Unlicensed and off label prescription of drugs to children: Population based cohort study. BMJ Br. Med. J., v.324, n.7349, p.1313-1314, 2002.

KAIRUZ, T.E.; GARGIULO, D.; BUNT, C.; GARG, S. Quality, safety and efficacy in the 'off-label' use of medicines. Curr. Drug Saf., v.2, n.1, p.89-95, 2007.

KELLER, R.L.; HMRICK, S.E.; KITTERMAN, J.A.; FINEMAN, J.R.; HAWGOOD, S. Treatment of rebound and chronic pulmonary hypertension with oral sildenafil in an infant with congenital diaphragmatic hernia. Pediatr. Crit. Care Med., v.5, n.2, p.184-187, 2004.

KOTHARI, S.S.; DUGGAL, B. Chronic oral sildenafil therapy in severe pulmonary artery hypertension. Indian Heart J., v.54, n.4, p.404-409, 2002.

LADHA, F.; BONNET, S.; EATON, F.; HASHIMOTO, K.; KORBUTT, G.; THÉBAUD, T. Sildenafil improves alveolar growth and pulmonary hypertension in hyperoxiainduced lung injury. Am. J. Respir. Crit. Care Med., v.172, n.6, p.750-756, 2005.

LEIBOVITCH, L.; MATOK, I.; PARET, G. Therapeutic applications of sildenafil citrate in the management of paediatric pulmonary hypertension. Drugs, v.67, n.1, p.5773, 2007.
MARTÍNEZ, E.G.; DE LROSA, I.I.; NAVERO, J.L.P.; MATEO, I.T.; MONTES, J.F.E.; CONDE, J.C. Sildenafil in the treatment of pulmonary hypertension. An. Pediatr. (Barc)., v.59, n.1, p.110-113, 2003.

NAHATA, M.C.; MOROSCO, R.S.; BRADY, M.T. Extemporaneous sildenafil citrate oral suspensions for the treatment of pulmonary hypertension in children. Am. $J$. Health Syst. Pharm., v.63, n.3, p.254-257, 2006.

NAMACHIVAYAM, P.; THEILEN, U.; BUTT, W.W.; COOPER, S.M.; PENNY, D.J.; SHEKERDEMIAN, L.S. Sildenafil prevents rebound pulmonary hypertension after withdrawal of nitric oxide in children. Am. J. Respir. Crit. Care Med., v.174, n.9, p.1042-1047, 2006.

PANDOLFINI, C.; BONATI, M. A literature review on off-label drug use in children. Eur. J. Pediatr., v.164, n.9, p.552-558, 2005.

SCHIRM, E.; TOBI, H.; BERG, L.T.W. Risk factors for unlicensed and off-Label drug use in children outside the hospital. Pediatrics, v.111, n.2, p.291-295, 2003.

SONI, M.G.; BURDOCK, G.A.; TAYLOR, S.L.; GREENBERG, N.A. Safety assessment of propyl paraben: a review of the published literature. Food Chem. Toxicol., v.39, n.6, p.513$532,2001$.

SONI, M.G.; TAYLOR, S.L.; GREENBERG, N.A.; BURDOCK, G.A. Evaluation of the health aspects of methyl paraben: A review of the published literature. Food Chem. Toxicol., v.40, n.10, p.1335-1373, 2002.

TAFURI, G.; TROTTA, F.; LEUFKENS, H.G.M.; MARTINI, M.; SAGLIOCCA L.; TRAVERSA, G. Off-label use of medicines in children: Can available evidence avoid useless paediatric trials? The case of proton pump inhibitors for the treatment of gastroesophageal reflux disease. Eur. J. Clin. Pharmacol., v.65, n.2, p. 209-216.

Received for publication on $11^{\text {th }}$ June 2012 Accepted for publication on $30^{\text {th }}$ January 2013 